\title{
Short communication: Genetic parameters of production traits in Chinese Holsteins using a random regression test-day model
}

\author{
F. Miglior, ${ }^{*} \dagger^{1,2}$ W. Gong, $\ddagger^{1}$ Y. Wang, $\dagger$ G. J. Kistemaker, $\dagger$ A. Sewalem, ${ }^{*} \dagger$ and J. Jamrozik§ \\ ${ }^{*}$ Agriculture and Agri-Food Canada, Dairy and Swine Research and Development Centre, Sherbrooke, Quebec, Canada, J1M 1 Z3 \\ †Canadian Dairy Network, Guelph, Ontario, Canada, N1G 4T2 \\ $\ddagger$ China Agricultural University, Beijing, China, 100193 \\ §Centre for the Genetic Improvement of Livestock, University of Guelph, Guelph, Ontario, Canada, N1G 2W1
}

\section{ABSTRACT}

The objective of this study was to estimate genetic parameters of production traits in the first 3 parities in Chinese Holsteins. Data were a random sample of complete herds $(109,005$ test-day records of 9,706 cows from 54 herds) extracted from the original data set, which included 362,304 test-day records of 30,942 Holstein cows from 105 herds. A test-day animal model with multiple-trait random regression and the Gibbs sampling method were used for parameter estimation. Regression curves were modeled using Legendre polynomials of order 4 . The multiple-trait analysis included milk, fat, and protein yield, and somatic cell score (SCS). Average daily heritabilities ranged between 0.222 and 0.346 for the yield traits and between 0.092 and 0.187 for SCS. Heritabilities were higher in the third lactation for all traits. Within-parity genetic correlations were very high among the yield traits $(>0.806)$ and were close to zero between SCS and yield traits, especially for first-parity cows. Results were similar to previous literature estimates from studies that used the same model as applied to this study. The estimates found in this study will be used to perform breeding value estimation for national genetic evaluations in Chinese Holsteins.

Key words: genetic parameter, random regression model, Chinese Holstein

The dairy cattle population in China has increased rapidly since 2000. It mainly consists of Holstein cattle imported from North America, Europe, and Australia, and their crossbred animals with local breeds. According to Chinese official statistics, at the end of 2007, there were 13.9 million dairy cattle in China, with an increase of $182 \%$ compared with year 2000 (Dairy As-

Received March 13, 2009.

Accepted April 29, 2009.

${ }^{1}$ These authors contributed equally to this work.

${ }^{2}$ Corresponding author: miglior@cdn.ca sociation of China, 2009). A dairy performance-testing program was begun in the 1990s with the support of the Sino-Japan Dairy Technical Cooperation Project and the Sino-Canada Integrated Dairy Cattle Breeding Program. Initially, the dairy performance-testing program was developed only in the cities of Tianjin, Shanghai, Beijing, Xi'an, and Hangzhou. In 2006, the Ministry of Agriculture of China approved a project to promote DHI services in 8 provinces where large dairy populations were located. Recently, this project has expanded to 16 provinces and a local provincial DHI laboratory was established with national funding. Data from the local DHIA flows to a central database at the Dairy Association of China. Currently more than 150,000 cows from 400 farms are milk recorded every year with an A4 test program (Dairy Association of China, 2009). To date, lactation sire and animal models have been used in China by using regional performance data for local genetic evaluation.

In January 2009, Interbull (2009) reported that $67 \%$ of countries $(\mathrm{n}=24)$ that participated in the international evaluations for production traits of Holstein bulls used a test-day model for national genetic evaluations, whereas the remaining countries used a lactation animal model (repeatability or multiple-lactation model). The number of countries moving to a test-day model continues to increase as France and Spain work toward implementing a test-day model. Research collaboration between China and Canada was initiated by the Dairy Association of China in 2006. The overall objective of the project was to develop a genetic evaluation system for production and conformation traits for the Chinese Holstein population. The objective of this study was to estimate variance components of milk, fat, and protein yield and SCS for Chinese Holstein cows by using a multiple-trait, multiple-lactation random regression test-day model.

Test-day records collected from 2002 to 2006 were provided for Chinese Holstein cows and included a total of 362,304 records of 30,942 cows from 105 herds. The original data set included animal registration number, 
Table 1. Descriptive statistics of test-day records in the complete edited data set

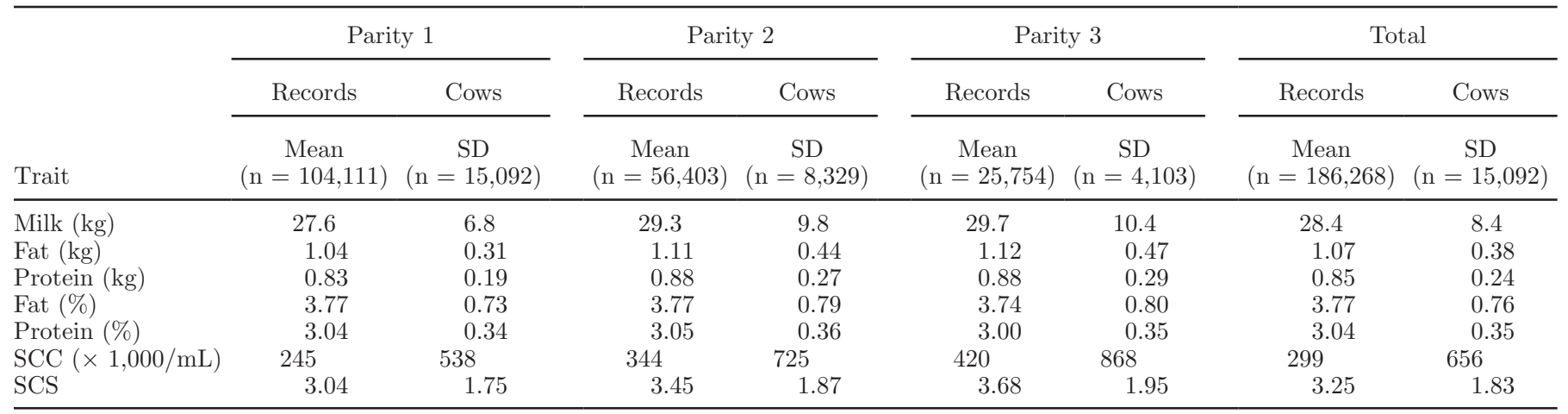

herd, calving date, test date, milk yield, fat and protein percentages, SCC, number of milkings per day, and a variable indicating supervised or unsupervised control. Full pedigree records were also provided by the Dairy Association of China (Beijing, China) and included 189,249 females and 7,236 males, with birth years ranging from 1916 to 2007. Records from DIM lower than 5 $\mathrm{d}$ and greater than $305 \mathrm{~d}$ were eliminated. Only records from the first 3 parities that had data for all production traits on a given test day were kept. Within cow, if parity 3 was present, parities 1 and 2 were also present, and if parity 2 was present, parity 1 was also present. Herds were required to have a minimum of 50 cows in the data set to be included in the analysis $(\sim 10$ cows per year). The final edited data set included 186,268 records of 24-h test-day milk, fat, protein yields and SCS observations for the first 3 lactations, from 15,092 cows from 65 herds. For computational purposes, a random sample of complete herds was extracted from the edited data set to estimate variance components. A total of 9,706 cows from 54 herds (average of 180 cows/herd) with 109,005 test-day records were randomly selected. The total number of animals (cows with their own records + pedigree) included 24,272 animals.
The 4-trait multiple-lactation random regression test-day model was

$$
\mathbf{y}=\mathbf{H h}+\mathbf{X b}+\mathbf{Z a}+\mathbf{W} \mathbf{p}+\mathbf{e}
$$

where $\mathbf{y}$ is a vector of 24-h test-day milk, fat, and protein yield and SCS [SCS $=\log _{2}(\mathrm{SCC} / 100,000)+$ $3]$ observations for the first 3 lactations; $\mathbf{h}$ is a vector of fixed herd-test-day effects; $\mathbf{b}$ is a vector of fixed regression coefficients for age-parity-season classes; a is a vector of random regression coefficients for genetic effects; $\mathbf{p}$ is a vector of random regression coefficients for permanent environmental (PE) effects; and $\mathbf{e}$ is a vector of residual effects. Incidence matrices $\mathbf{H}, \mathbf{X}, \mathbf{Z}$, and $\mathbf{W}$ relate observations to their respective effects. Age-parity-season classes were 16 age classes for parity 1, 12 for parity 2 , and 10 for parity 3 . Two seasons of calving were used, with April through September defined as season 1, and October through March defined as season 2. Regression curves were modeled using Legendre polynomials of order 4 as defined by Jamrozik et al. (2002).

The distribution of random effects was assumed to be

Table 2. Descriptive statistics of test-day records in the random sample used for variance component estimation

\begin{tabular}{|c|c|c|c|c|c|c|c|c|}
\hline \multirow[b]{2}{*}{ Trait } & \multicolumn{2}{|c|}{ Parity 1} & \multicolumn{2}{|c|}{ Parity 2} & \multicolumn{2}{|c|}{ Parity 3} & \multicolumn{2}{|c|}{ Total } \\
\hline & $\begin{array}{c}\text { Mean } \\
(\mathrm{n}=61,405)\end{array}$ & $\begin{array}{c}\text { SD } \\
(\mathrm{n}=9,706)\end{array}$ & $\begin{array}{c}\text { Mean } \\
(\mathrm{n}=32,598)\end{array}$ & $\begin{array}{c}\mathrm{SD} \\
(\mathrm{n}=5,102)\end{array}$ & $\begin{array}{c}\text { Mean } \\
(\mathrm{n}=15,002)\end{array}$ & $\begin{array}{c}\text { SD } \\
(\mathrm{n}=2,496)\end{array}$ & $\begin{array}{c}\text { Mean } \\
(\mathrm{n}=109,005)\end{array}$ & $\begin{array}{c}\text { SD } \\
(\mathrm{n}=9,706)\end{array}$ \\
\hline Milk (kg) & 27.4 & 6.8 & 29.2 & 9.7 & 29.6 & 10.5 & 28.3 & 8.4 \\
\hline Fat $(\mathrm{kg})$ & 1.05 & 0.32 & 1.11 & 0.44 & 1.13 & 0.49 & 1.08 & 0.39 \\
\hline Protein (\%) & 3.05 & 0.34 & 3.06 & 0.37 & 3.01 & 0.36 & 3.05 & 0.35 \\
\hline $\mathrm{SCC}(\times 1,000 / \mathrm{mL})$ & 252 & 549 & 333 & 724 & 411 & 907 & 298 & 666 \\
\hline SCS & 3.08 & 1.75 & 3.37 & 1.87 & 3.58 & 1.96 & 3.24 & 1.83 \\
\hline
\end{tabular}


Table 3. Raw phenotypic correlations among production traits

\begin{tabular}{lccrrrr}
\hline Item & Fat $(\mathrm{kg})$ & Protein $(\mathrm{kg})$ & Fat $(\%)$ & Protein $(\%)$ & SCC & SCS \\
\hline Milk $(\mathrm{kg})$ & 0.803 & 0.925 & -0.036 & -0.390 & -0.126 & -0.223 \\
Fat $(\mathrm{kg})$ & & 0.772 & 0.541 & -0.238 & -0.092 & -0.166 \\
Protein $(\mathrm{kg})$ & & 0.025 & -0.034 & -0.099 & -0.180 \\
Fat $(\%)$ & & & 0.181 & 0.018 & 0.021 \\
Protein $(\%)$ & & & & 0.113 & 0.169 \\
SCC $(\times 1,000 / \mathrm{mL})$ & & & & & 0.682 \\
\hline
\end{tabular}

$$
\left(\begin{array}{l}
\mathbf{a} \\
\mathbf{p} \\
\mathbf{e}
\end{array}\right) \sim N(0, \mathbf{V})
$$

with variances

$$
\mathbf{V}=\left(\begin{array}{ccc}
\mathbf{G} \otimes \mathbf{A} & \mathbf{0} & \mathbf{0} \\
\mathbf{0} & \mathbf{I} \otimes \mathbf{P} & \mathbf{0} \\
\mathbf{0} & \mathbf{0} & \sum+\mathbf{R}^{\mathrm{p}, \mathrm{s}}
\end{array}\right),
$$

where $\mathbf{G}$ and $\mathbf{P}$ are covariance matrices for genetic and $\mathrm{PE}$ regression coefficients, respectively; $\mathbf{A}$ is the additive relationship matrix; $\mathbf{I}$ is an identity matrix; and
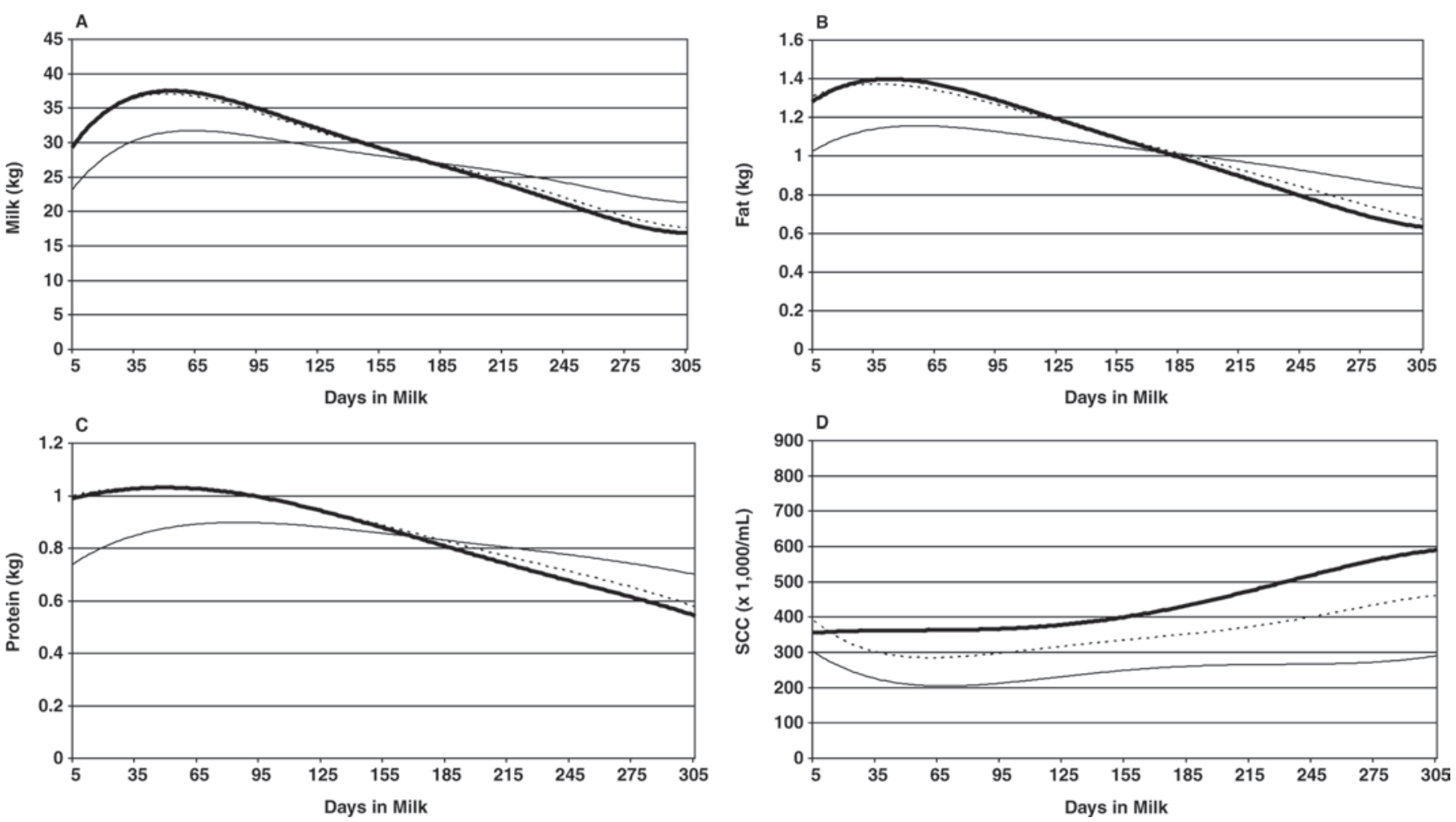

Figure 1. Average traits by DIM: A) milk (kg); B) fat (kg); C) protein (kg); and D) SCC ( $\times 1,000 / \mathrm{mL})$. First parity, thin solid line; second parity, dashed line; third parity, thick solid line. 


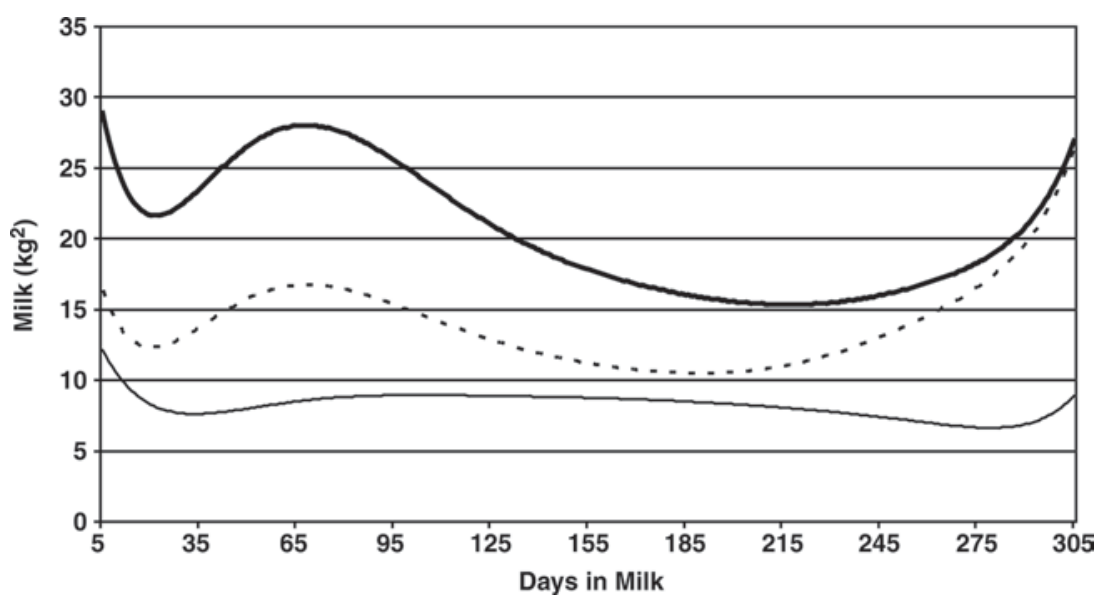

Figure 2. Genetic variance of milk yield by DIM. First parity, thin solid line; second parity, dashed line; third parity, thick solid line.

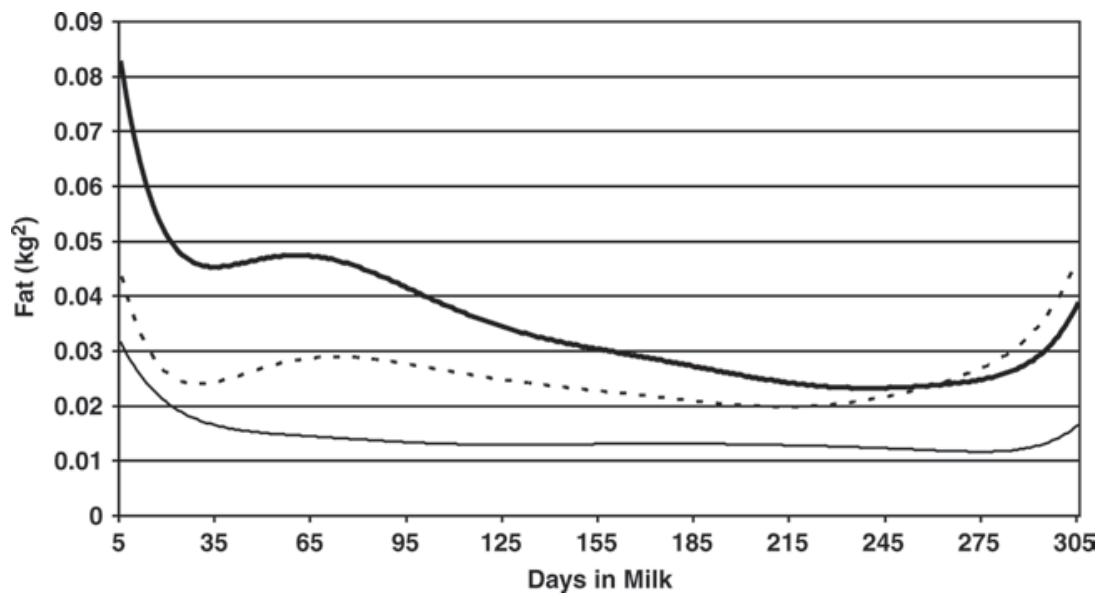

Figure 3. Genetic variance of fat yield by DIM. First parity, thin solid line; second parity, dashed line; third parity, thick solid line.

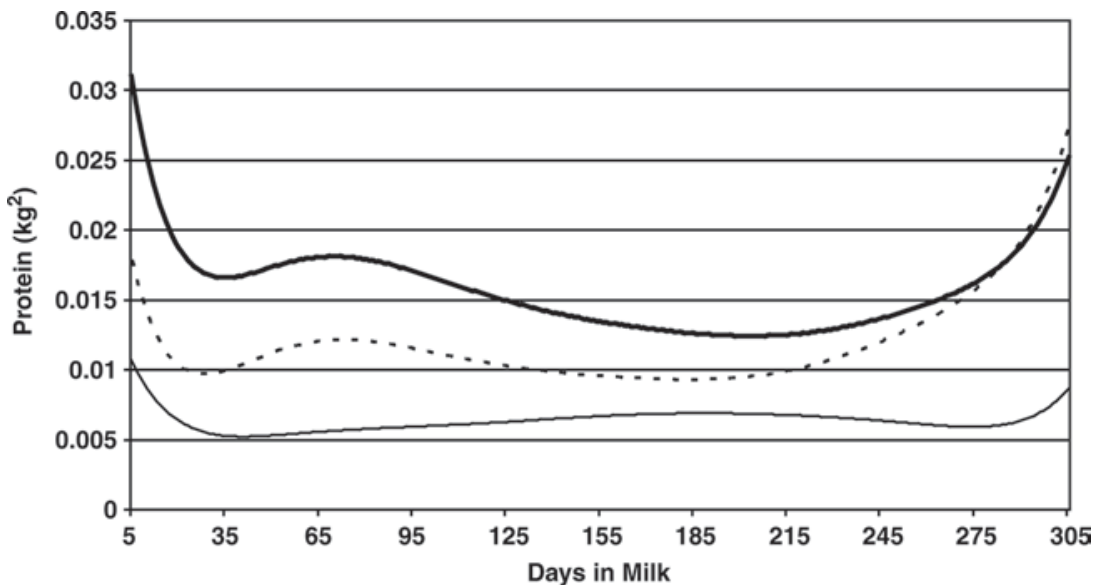

Figure 4. Genetic variance of protein yield by DIM. First parity, thin solid line; second parity, dashed line; third parity, thick solid line. 


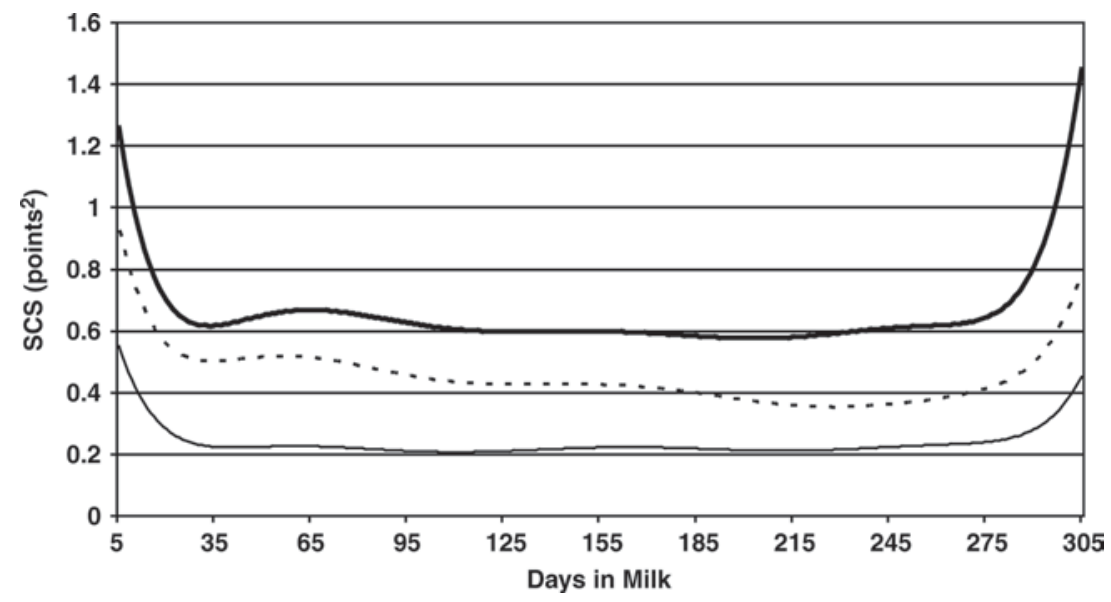

Figure 5. Genetic variance of SCS by DIM. First parity, thin solid line; second parity, dashed line; third parity, thick solid line.

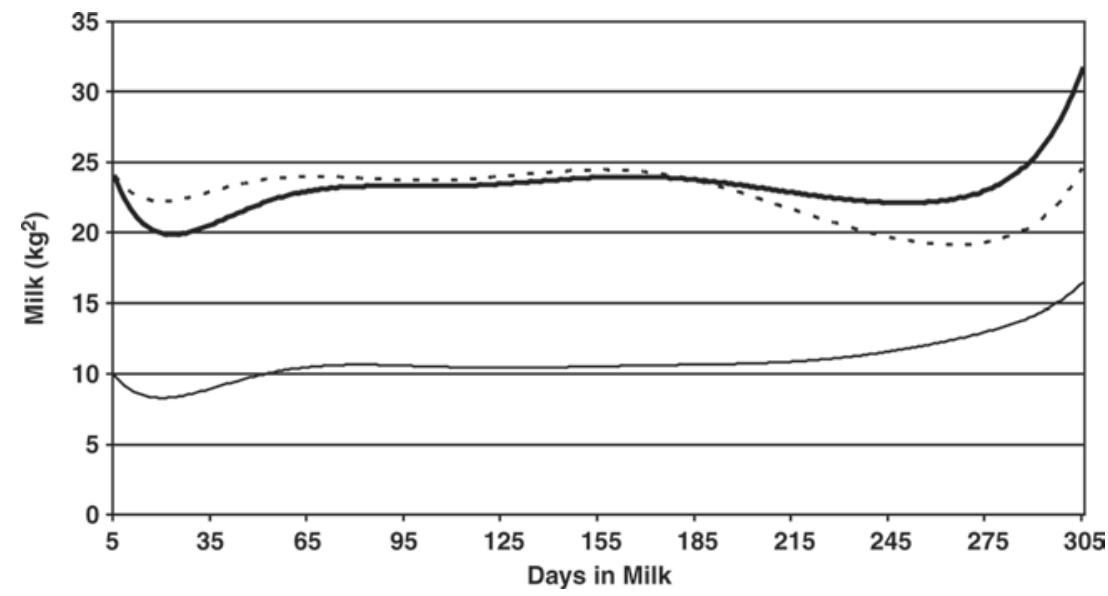

Figure 6. Permanent environmental variance of milk yield by DIM. First parity, thin solid line; second parity, dashed line; third parity, thick solid line.

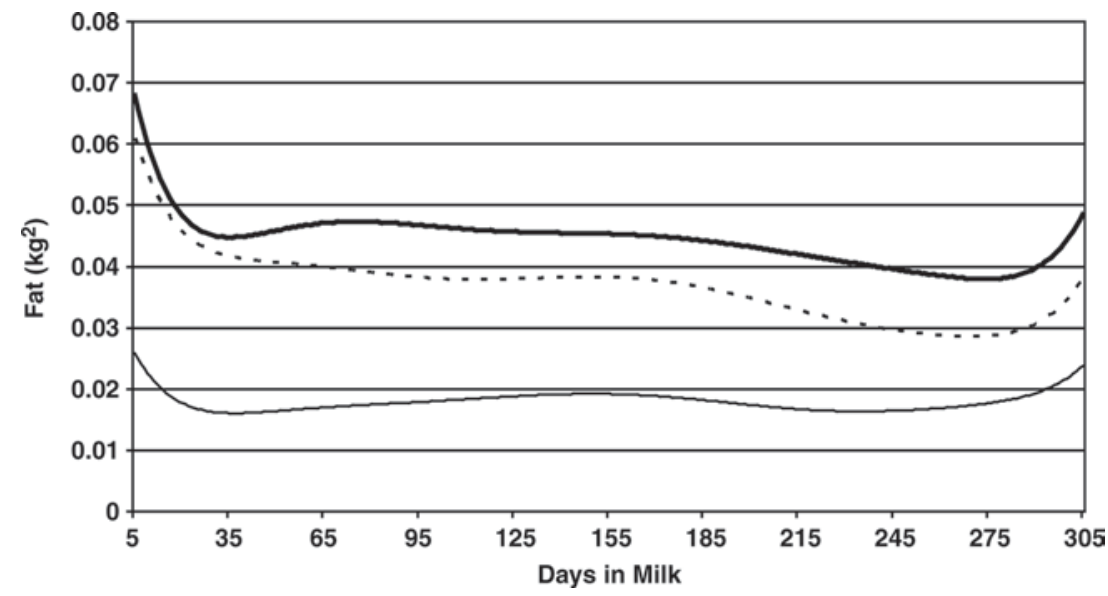

Figure 7. Permanent environmental variance of fat yield by DIM. First parity, thin solid line; second parity, dashed line; third parity, thick solid line. 
Table 4. Average daily heritabilities (on the diagonal), genetic correlations (below the diagonal), and permanent environment correlations (above the diagonal)

\begin{tabular}{|c|c|c|c|c|c|c|c|c|c|c|c|c|}
\hline \multirow[b]{2}{*}{ Item } & \multicolumn{4}{|c|}{ Parity 1} & \multicolumn{4}{|c|}{ Parity 2} & \multicolumn{4}{|c|}{ Parity 3} \\
\hline & Milk (kg) & Fat $(\mathrm{kg})$ & Protein $(\mathrm{kg})$ & SCS & Milk (kg) & Fat $(\mathrm{kg})$ & Protein $(\mathrm{kg})$ & SCS & Milk (kg) & Fat $(\mathrm{kg})$ & Protein $(\mathrm{kg})$ & SCS \\
\hline Milk (kg) & 0.291 & 0.880 & 0.944 & -0.169 & 0.444 & 0.397 & 0.440 & -0.009 & 0.311 & 0.264 & 0.304 & 0.051 \\
\hline Fat $(\mathrm{kg})$ & 0.833 & 0.222 & 0.874 & -0.170 & 0.386 & 0.421 & 0.424 & -0.055 & 0.270 & 0.294 & 0.307 & -0.010 \\
\hline Protein $(\mathrm{kg})$ & 0.924 & 0.854 & 0.251 & -0.121 & 0.405 & 0.383 & 0.444 & -0.025 & 0.303 & 0.274 & 0.333 & 0.060 \\
\hline SCS & -0.118 & -0.180 & -0.100 & 0.092 & -0.125 & -0.145 & -0.119 & 0.343 & -0.139 & -0.142 & -0.139 & 0.194 \\
\hline Fat $(\mathrm{kg})$ & 0.401 & 0.550 & 0.475 & -0.131 & 0.806 & 0.242 & 0.939 & -0.330 & 0.377 & 0.408 & 0.385 & -0.088 \\
\hline Protein $(\mathrm{kg})$ & 0.477 & 0.423 & 0.574 & -0.049 & 0.939 & 0.839 & 0.264 & -0.268 & 0.381 & 0.367 & 0.397 & -0.052 \\
\hline SCS & 0.018 & 0.003 & 0.094 & 0.523 & -0.201 & -0.191 & -0.098 & 0.151 & -0.109 & -0.125 & -0.127 & 0.429 \\
\hline \multicolumn{13}{|l|}{ Parity 3} \\
\hline Milk (kg) & 0.480 & 0.325 & 0.429 & -0.064 & 0.824 & 0.629 & 0.742 & -0.224 & 0.346 & 0.943 & 0.973 & -0.214 \\
\hline Fat $(\mathrm{kg})$ & 0.371 & 0.396 & 0.380 & -0.127 & 0.711 & 0.730 & 0.684 & -0.237 & 0.888 & 0.262 & 0.930 & -0.243 \\
\hline Protein (kg) & 0.399 & 0.311 & 0.442 & -0.039 & 0.765 & 0.633 & 0.772 & -0.167 & 0.949 & 0.888 & 0.314 & -0.192 \\
\hline
\end{tabular}

tions of (co)variance components were estimated using 90,000 samples after a burn-in of 10,000 samples. The convergence of Gibbs sampler was monitored by visual inspection of the plot of realizations for selected covariance components. Daily heritability was defined as a ratio of genetic variance to the sum of genetic, $\mathrm{PE}$, and residual variances for each DIM from 5 to $305 \mathrm{~d}$, and averaged across the entire lactation for each of the first 3 lactations. Genetic correlations were calculated using (co)variances of the first random regression coefficients as described by Wood et al. (2003).

In this study, SCC was analyzed to estimate phenotypic correlations and phenotypic lactation curves, whereas SCS was analyzed to estimate variance components. Descriptive statistics of the complete edited data set $(\mathrm{n}=15,092)$ and of the random sample data set used for parameter estimation $(\mathrm{n}=9,706)$ for all production traits by parity are shown in Tables 1 and 2 , respectively. With the exception of fat percentage, means and standard deviations for all traits were very similar between data sets. Table 3 shows raw phenotypic correlations among all traits in the original edited data set. The correlation between milk yield and fat percentage was close to zero, as was the correlation between protein yield and protein percentage. Protein percentage was negatively correlated with milk yield. All yields were highly correlated, whereas SCC was weakly correlated with all traits.

Figure 1A to $1 \mathrm{D}$ shows trajectories of milk, fat, and protein yield and SCC by DIM for each parity. The curves were interpolations of phenotypic daily averages in the original edited data set by using polynomials

Table 5. Differences between estimated parameters ${ }^{1}$ from the current study ${ }^{2}$ and parameters estimated by Muir et al. (2004)

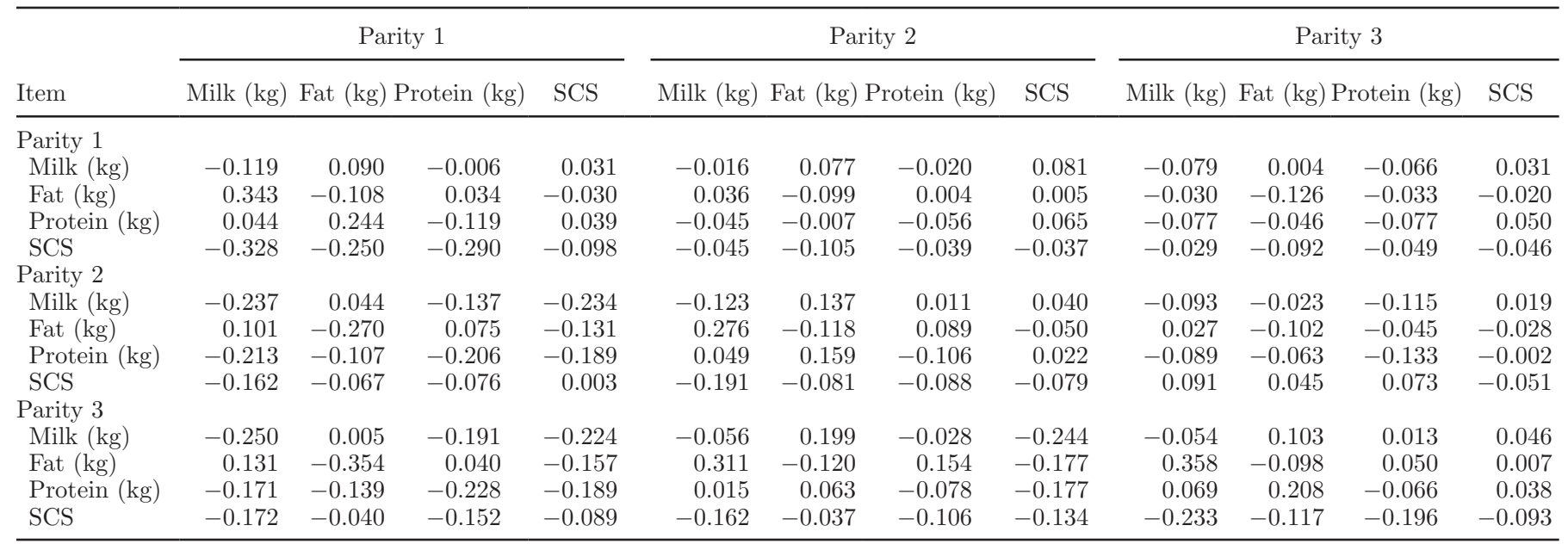

${ }^{1}$ Average daily heritabilities (on the diagonal), genetic correlations (below the diagonal), and permanent environment correlations (above the diagonal).

${ }^{2}$ See Table 4 . 
Table 6. Differences between estimated parameters ${ }^{1}$ from the current study ${ }^{2}$ and parameters estimated by Miglior et al. (2007)

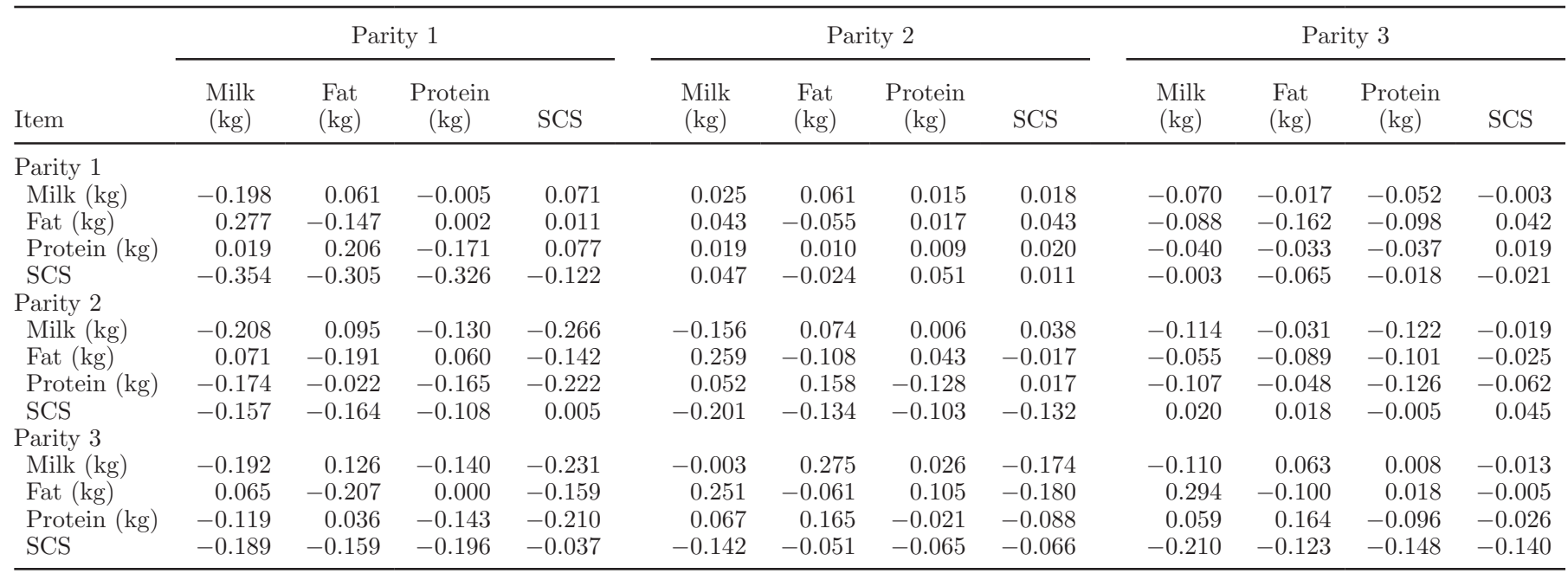

${ }^{1}$ Average daily heritabilities (on the diagonal), genetic correlations (below the diagonal), and permanent environment correlations (above the diagonal).

${ }^{2}$ See Table 4.

of the fourth order, with $\mathrm{R}^{2}$ ranging from 0.96 to 0.99 for milk, fat, and protein yield, and from 0.40 to 0.47 for SCC. The curves for milk yield were similar to the lactation curves found previously in literature, with the first parity being more persistent but the second and third parities having higher peak yields and then declining more significantly than the first-parity average lactation. One difference with previous studies should be observed: in the latter part of the lactation, average first-parity production was higher than in later parities. Curves for fat yield had the same pattern as those for milk yield. The curves for protein yield had a different pattern than the milk and fat lactation curves, with the peak not being as high as in the rest of the lactation. In relative terms, curves for SCC across the 3 parities were as expected: a) lower SCC at the time of the milk yield peak and increasing to higher SCC for the rest of the lactation, and b) an average level of SCC increases over later parities.

Figures 2 to 5 show the genetic variance by DIM for milk, fat, and protein yield and SCS in each parity. The spikes seen previously at the beginning and end of the

Table 7. Differences between estimated parameters ${ }^{1}$ from the current study $^{2}$ and parameters estimated by Muir et al. (2007)

\begin{tabular}{|c|c|c|c|c|c|c|c|c|c|c|c|c|}
\hline Item & \multicolumn{4}{|c|}{ Parity 1} & \multicolumn{4}{|c|}{ Parity 2} & \multicolumn{4}{|c|}{ Parity 3} \\
\hline \multicolumn{13}{|l|}{ Parity 1} \\
\hline Milk (kg) & -0.009 & 0.020 & -0.026 & 0.011 & -0.036 & 0.027 & -0.030 & 0.001 & -0.049 & -0.036 & -0.056 & 0.001 \\
\hline Fat $(\mathrm{kg})$ & 0.323 & -0.048 & -0.006 & -0.020 & -0.014 & -0.079 & -0.016 & -0.035 & 0.000 & -0.096 & -0.023 & -0.030 \\
\hline Protein (kg) & 0.044 & 0.234 & -0.029 & 0.029 & -0.065 & -0.027 & -0.056 & -0.015 & -0.037 & -0.056 & -0.057 & 0.000 \\
\hline Milk (kg) & -0.217 & 0.014 & -0.147 & -0.104 & -0.023 & 0.067 & 0.001 & -0.030 & -0.053 & -0.053 & -0.095 & -0.061 \\
\hline Fat $(\mathrm{kg})$ & 0.001 & -0.270 & -0.015 & -0.041 & 0.176 & -0.048 & 0.039 & -0.060 & 0.047 & -0.072 & -0.015 & -0.078 \\
\hline Protein (kg) & -0.193 & -0.117 & -0.216 & -0.079 & 0.039 & 0.109 & -0.036 & -0.048 & -0.049 & -0.073 & -0.093 & -0.082 \\
\hline SCS & -0.112 & 0.003 & -0.036 & 0.033 & -0.171 & -0.101 & -0.088 & -0.059 & 0.031 & 0.035 & 0.023 & -0.011 \\
\hline \multicolumn{13}{|l|}{ Parity 3} \\
\hline Milk (kg) & -0.220 & -0.025 & -0.201 & -0.114 & -0.036 & 0.119 & -0.038 & -0.204 & 0.016 & 0.063 & 0.003 & 0.016 \\
\hline Fat $(\mathrm{kg})$ & 0.001 & -0.354 & -0.090 & -0.107 & 0.201 & -0.110 & 0.054 & -0.177 & 0.228 & -0.048 & 0.020 & 0.007 \\
\hline
\end{tabular}

${ }^{1}$ Average daily heritabilities (on the diagonal), genetic correlations (below the diagonal), and permanent environment correlations (above the diagonal).

${ }^{2}$ See Table 4. 
MIGLIOR ET AL.

Table 8. Residual variances by parity and stage of lactation for milk, fat, and protein yield and for SCS

\begin{tabular}{|c|c|c|c|c|}
\hline Item & $\begin{array}{c}\text { Period } 1 \\
(5 \text { to } 45 \text { DIM })\end{array}$ & $\begin{array}{c}\text { Period } 2 \\
\text { (46 to } 115 \text { DIM) }\end{array}$ & $\begin{array}{c}\text { Period } 3 \\
\text { (116 to } 265 \text { DIM) }\end{array}$ & $\begin{array}{c}\text { Period } 4 \\
\text { (266 to } 305 \text { DIM }\end{array}$ \\
\hline \multicolumn{5}{|l|}{ Parity 1} \\
\hline Milk (kg) & 13.2281 & 9.2489 & 8.3405 & 7.6582 \\
\hline Fat $(\mathrm{kg})$ & 0.0413 & 0.0369 & 0.0278 & 0.0223 \\
\hline $\begin{array}{l}\text { Protein } \\
(\mathrm{kg})\end{array}$ & 0.0124 & 0.0103 & 0.0096 & 0.0095 \\
\hline SCS & 1.6147 & 1.4588 & 1.3727 & 1.2331 \\
\hline \multicolumn{5}{|l|}{ Parity 2} \\
\hline Milk (kg) & 23.4510 & 15.7636 & 11.7337 & 8.3377 \\
\hline Fat $(\mathrm{kg})$ & 0.0760 & 0.0618 & 0.0373 & 0.0213 \\
\hline $\begin{array}{l}\text { Protein } \\
(\mathrm{kg})\end{array}$ & 0.0226 & 0.0165 & 0.0132 & 0.0110 \\
\hline SCS & 1.8346 & 1.7604 & 1.5398 & 1.3952 \\
\hline \multicolumn{5}{|l|}{ Parity 3} \\
\hline Milk (kg) & 24.8615 & 17.2124 & 13.7012 & 8.5215 \\
\hline Fat (kg) & 0.0889 & 0.0757 & 0.0410 & 0.0220 \\
\hline $\begin{array}{l}\text { Protein } \\
(\mathrm{kg})\end{array}$ & 0.0209 & 0.0176 & 0.0146 & 0.0112 \\
\hline SCS & 1.9318 & 2.0469 & 1.6081 & 1.2042 \\
\hline
\end{tabular}

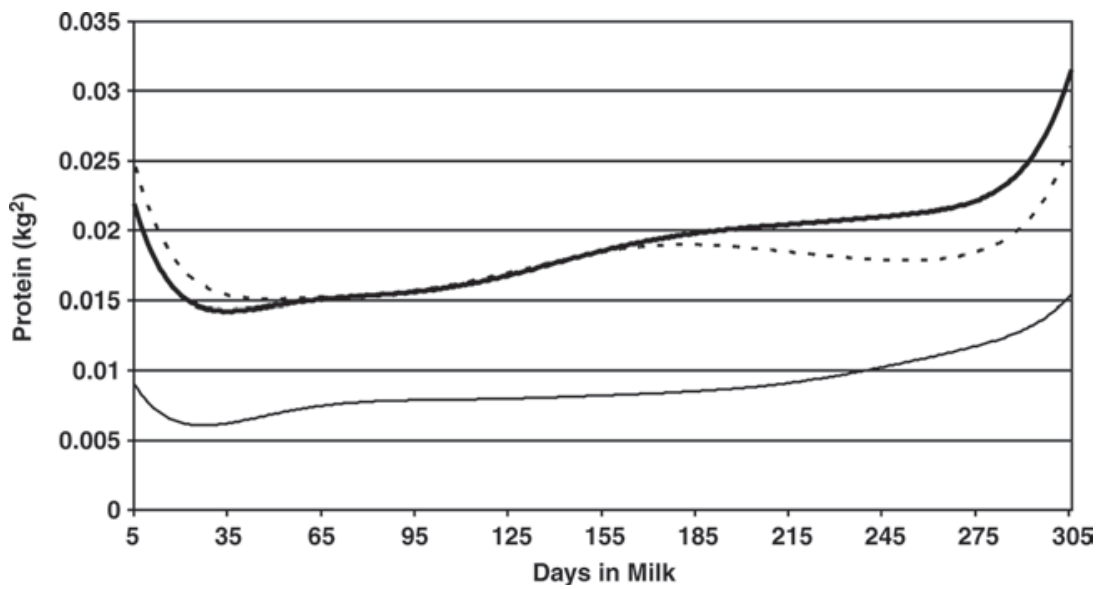

Figure 8. Permanent environmental variance of protein yield by DIM. First parity, thin solid line; second parity, dashed line; third parity, thick solid line.

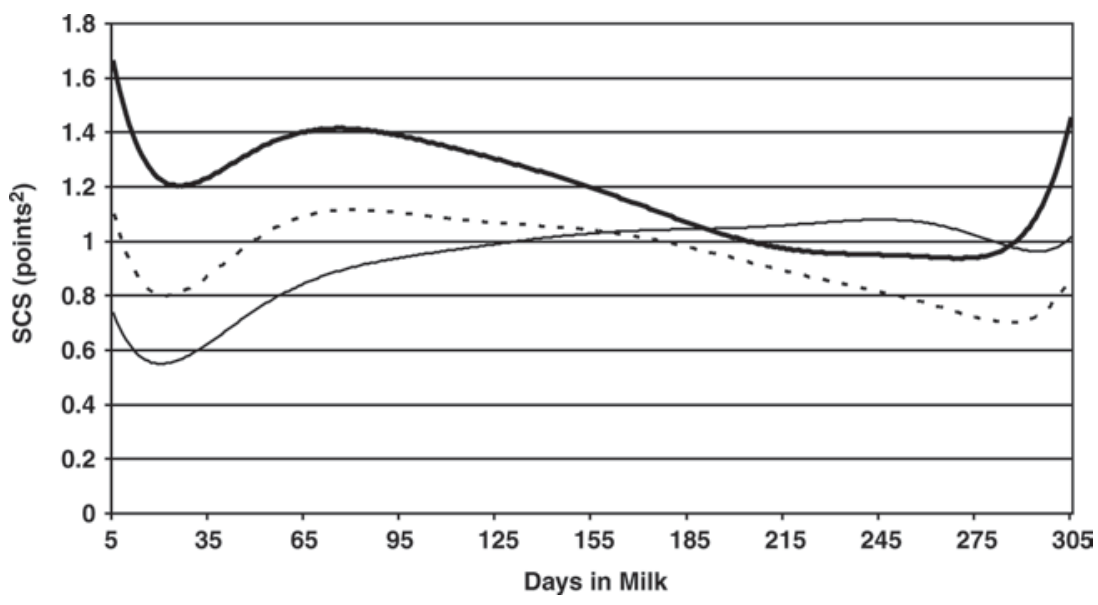

Figure 9. Permanent environmental variance of SCS by DIM. First parity, thin solid line; second parity, dashed line; third parity, thick solid line. 
lactation were also observed in this study. For the yield traits, genetic variance was quite constant for firstparity cows, whereas it was more variable in the first and last part of lactation for second- and third-parity cows. For SCS, genetic variance was constant over the lactation across the 3 parities. Figures 6 to 9 show the PE variance by DIM for milk, fat, and protein yield and SCS in each parity. Overall, PE variances had more irregular trends over the lactation when compared with genetic variances. However, the magnitude of $\mathrm{PE}$ variances was similar to the magnitude of the respective genetic variances. Genetic and PE correlations and daily heritabilities are shown in Table 4 for the 4 traits and 3 parities. Posterior standard deviations of all estimates (heritability, genetic, and PE correlations) ranged from 0.001 to 0.009 . On average across the 4 traits, heritabilities tended to increase in later parities. Within parities, milk, fat, and protein were highly correlated among each other, whereas SCS had a low negative correlation with the production traits, but its magnitude increased in later parities. The same model used to estimate (co) variances in this study has also been used recently in 3 previous investigations: a) Canadian Holsteins (Muir et al., 2004; $\mathrm{n}=12,411$ ); b) Quebec Holsteins (Miglior et al., 2007; $\mathrm{n}=5,022$ ); and c) Italian Holsteins (Muir et al., 2007; $\mathrm{n}=10,275$ ). Tables 5, 6, and 7 show the differences between estimated correlations and heritabilities from the current study and those parameters estimated in the 3 above-mentioned investigations. There was very little difference among studies for the $\mathrm{PE}$ correlations (average less than 3\%). Heritabilities from the current study were slightly lower than heritabilities for Italian Holsteins (average difference $=-0.036$ ), but were markedly lower than heritabilities for the $2 \mathrm{Ca}$ nadian studies (average difference $=-0.116$ ). Within parity, genetic correlations between milk and fat yield were much higher in the Chinese Holsteins than the Canadian Holsteins (average difference $=+0.326$ ), the Quebec Holsteins (average difference $=+0.277$ ), and the Italian Holsteins (average difference $=+0.242$ ). In addition, within parity, genetic correlations between fat and protein yield were higher in the Chinese Holsteins than in 3 other previously studied populations (average difference $=+0.180$ ), whereas within parity, genetic correlations between milk and protein yield were slightly higher in the Chinese Holsteins than in 3 other previously studied populations (average difference = $+0.047)$. Genetic correlations between SCS and the other production traits were lower than in the 3 other previously studied populations (average difference $=$ -0.189). Genetic correlations between and within traits across parities were generally lower in the Chinese Holsteins than in the 3 other previously studied populations, especially between first and later parities. 
Table 8 includes residual variances by parity and stage of lactation for milk, fat, and protein yield, and SCS. Residual variances in the first period of lactation were higher than in the other periods across parities and traits. The only exception was for SCS in the third parity, when the residual variance in the second period of lactation was higher than in the first period. Overall, residual variances were similar to genetic variances for yield traits and were greater than genetic variances for SCS. Table 9 shows residual correlations, within parity and DIM period, among milk, fat, and protein yield, and SCS. Residual correlations were moderate and positive among yield traits across parities and DIM periods. Correlations were consistently small and close to zero across parities and periods between yield traits and SCS.

Genetic parameters were estimated for Chinese Holstein cows using a random regression test-day model. Results were similar to previous literature estimates from studies that used the same model as applied in this study. The estimates found in this study can be used to perform breeding value estimations for national genetic evaluations in Chinese Holsteins using a multiple-trait, multiple-lactation random regression model.

\section{REFERENCES}

Dairy Association of China. 2009. China Dairy Yearbook 2008. China Agriculture Press, Beijing, China.

Interbull. 2009. Interbull routine genetic evaluation for dairy production traits, January 2009. http://www-interbull.slu.se/eval/jan09.html Accessed Feb. 20, 2009.

Jamrozik, J., L. R. Schaeffer, and K. A. Weigel. 2002. Estimates of genetic parameters for single- and multiple-country test-day models. J. Dairy Sci. 85:3131-3141.

Miglior, F., A. Sewalem, J. Jamrozik, J. Bohmanova, D. M. Lefebvre, and R. K. Moore. 2007. Genetic analysis of milk urea nitrogen and lactose and their relationships with other production traits in Canadian Holstein cattle. J. Dairy Sci. 90:2468-2479.

Muir, B. L., G. Kistemaker, J. Jamrozik, and F. Canavesi. 2007. Genetic parameters for a multiple-trait multiple-lactation random regression test-day model in Italian Holsteins. J. Dairy Sci. 90:1564-1574.

Muir, B. L., G. Kistemaker, and B. J. Van Doormaal. 2004. Estimation of genetic parameters for the Canadian Test Day Model with Legendre polynomials for Holsteins based on more recent data [mimeo]. A Report to the Genetic Evaluation Board, April 2004. http://cgil.uoguelph.ca/dcbgc/Agenda0403/GEB\%20 Legendre\%20for\%20ANAFI\%20-\%20March\%202004.pdf Accessed Jan. 29, 2009.

Wood, G. M., P. J. Boettcher, J. Jamrozik, G. B. Jansen, and D. F Kelton. 2003. Estimation of genetic parameters for concentration of milk urea nitrogen. J. Dairy Sci. 86:2462-2469. 